\title{
Strategic Entrepreneurship
}

\author{
Ph.D. Branislav Djordjevic, Emeritus
}

\section{Doi:10.5901/mjss.2013.v4n16p127}

\begin{abstract}
There is a wide variety of types of entrepreneurs, but no one formula for success. However, there are many successful entrepreneurs. Understanding why some entrepren- eurs succeed while others fail is important to help future entrepreneurs in their efforts to be ssuccessful. Entrepreneurship is the economic engine driving many nations" econom- ies in the global competitive landscape. Entrepreneurship and innovation have become important for young and old and for large and small firms in all types of industries. Res- earch conducted has shown that in receant years almost 100 percent of the new jobs in the United States were created by entrepreneurial firms of less than two years age".) As result, this chapter focuses on strategic entrepreneurship.
\end{abstract}

Keywords: Consumer, organization, research, implication, environment influence, etc.

\section{The definition of strategic entrepreneurship}

Strategic entrepreneurship is taking entrepreneurial action using a strategic per- spective. More specifically, it involves engaing in simultaneous opportunity seeking and competitive advantage seeking behaviors to design implement entrepreneurial strategies to create wealth.). These actions can be taken by individuals or by corporations. Such activity in particularly important in the evolving 21-st century landscspe.

The competitive lanscape that has evolved in the 21-st century presents firms with sustantial change, a global marketplace, and significant complexity and uncertainty.). Because of this uncertain envornment, firms cannot easily predict the future. As a result, they must develop strategic flexibility to have a range of strategic alternatives that they can implement as needed. To do so, they must acquire resources and build the capabiliti- es that allow them to take necessary actions to adapt to a dynamic environment or to pro- act in that environment. In this environment, entrepreneurs and entrepreneurial managers design and implement actions that capture more of existing markets from less aggressive and innovative competitors while creating new markets). In effect, they are trying to cr- eate tomorrow's business.

Creating tomorrows's business requires identifying opportunities, and developing innovation. In other words, firms must be entreprenurial and innovative. Innovations are critical to companies' efforts to differentiate their goods or services from competitors in ways that create additional or new value for customers. Thus, entrepreneurial competen- cies are important for firms to achieve and sustain competitive advantage for a period of time.

To describe how firms produce and manage innovation, we examine several topics in this chapter. To set the stage, we first examine entrepreneurship and innovation in a strategic contex. Next, we discusss international entrepreneurship, a phenomenon reflecting the increase use of entrepreneurship in countries throughout the world. Interna- lly, firms innovate through either autonomous or induced strategic behavior. After our de- sciption of these internal corporate venturing activities, we discuss astions taken by firms to implement the innovations resulting from those two tepes of strategic behavior. In addition to innovating through internal activities, firms can gain access to other companies' innovations or innovative capabilities through strategic alliances and acquisitions. Following our discussion of these topics is a description of entrepreneurship in start-up ventures and smaller firms. This section closes both the chapter and our analysis of acti- ons that firms take to successfully implement strategies. 


\section{The Differences between Strategic Entreprenurship and Innovation}

Joseph Schumpeter viewed entrepreneurship as a process of "creative descripti- on" through which existing products or methods of production are destroyed and replaced with new ones. Thus, entreprenurship is "concerned with the discovery and exploitation of profitable opportunities."). Entrepreneurial activity is an important mechanism for cr- eating changes, as well as for helping firms adapt to changes created by others. Firms th- at encourage entreprenurship are risk takers, are commited to innovation, and act proacti- vely in that they try to create opportunities rather than waiting to respond to opportunities created by others.

Entrepreneurial opportunities represent conditions in which new products or services can satisfy a need in the market. The essence of entrepreneurship is to identify and exploit these opportunities. Importantly, enterpreneurs or entrepreneurial managers must be able to identify opportunities not perceived by others. Identifying these opportu- nities in a dynamic and uncertain environment requires an enterpreneurial mind-set that entails the passionate pursuitt of opportunities.).

After identifying the opportunities, enterpreneurs take action to exploit them and establish a competitive advantage. The process of identifying and pursuing opportunities is entrepreneurial, but this activity alone is rarely enough to create maximum wealth or even to survive over time. Actions must be valuable, rare, diffucult to imitate and non-substitutable to create and sustain a competitive advantage. Without the competitive adv- antage, success will be only temporary. An innovation may be valuable and rare early in its life, if a market perspective is used in its development. Hawoever, strategic action must be taken to introduce the new product to the market and protect its position in the market against competitors (difficult to imaitate) to gain a competitive advantage. These actions combined represent strategic entrepreneurship.

Peter Drucker argues that "innovation is the specific function of entrepreneursh- ip, whether in an existing business, a public service institution, or a new venture started by a lone individual". Moreover, Drucker suggests that innovation is " the means by wh- ich the entrpreneur either creates new wealth producing resources or endows existing resources with enhanced potential for creating wealth".) Thus, enterpreneurship and the innovation resulting from it are important for large and small firms, as well as for start-up ventures, as they compete in the 21st century competitive landscape. Therefore, we can conclude that, "Entrepreneurship and innovation are central to the creative process in the economy and to promoting growth, increasing productivity and creating jobs."

Innovation is a key ourcome firms seek through entrepreneurship and is often the source of competitive success. In Rosabeth Moss Kanter's words "Winning in busin- ess today demands innovation. Companies that innovate reap all the advantage of a first mover.").

For example, research results show that firms competing in global industries that invest more in innovation also achieve the highest returns. In fact, investors often react positively to the introduction of a new product, thereby increasing the price of a firm's stock. Innovation is an essential feature of highperformance firms. Furthemore, "in- novation may be required to maintain or achieve competitive parity, much less a compet- itive advantage in many global markets.

In his classic work, Schumpeter argued that firms engage in three types of inno- vative activity.). Invention is the act of creating or developing a new product or proc- ess. Innovation is the process of creating a commercial product from an invention. Thus, an innvention brings something new into being, while an innovation brings something new into use. Accordingly, tehnical criteria are used to determine the success of an invention, whereas commercial criteria are used to determine the successs of invention, whereas commercial criteria are used to determine the success of an innovation. Finally, imitation is the adoption of an innovation by simple firms. Imitation usaually leads to product or process standardization, and product based on imitation often are offered at lower prices, but without as many features.

In the Unitaed States in particular, innovation is the most critical of the three types of innovative activity that occur in firms. Many companies are able to create ideas that lead to inventions, but commercializing those inventions through innovations has, at times, proved difficult. Appproximately 80 percent of R\&D occurs 
in large firms, but these same firms produce fewer than 50 percent of the patents.

Innovations produced in large established firms are often referred to as corporate entrepreneurship. Corporate entrepreneurship is a proces whereby an individual or gr- oup in an exicting organization creates a new venture or develops an innovation. Over- all, corporate entreprenurship is the sum of a firm's innovation, renewal and venturing efforts. Evidence suggests that corporate entrepreneurship practices are facilitated throu- gh the effective use of a firm's strategic management process and effectively using the firm's human capital. Determining how to harmess the ingenuity of a firm's employees and how to reward them for while retaining some of the rewards of the entrepreneurial efforts for the shareholders' benefit facilitates the energency of value-creating corporate entrepreneurship.).

Many people tend not to distinquish between effectivenes and efficency. Yet effectiveness stressess the need for actions to attain goals, whereas efficency relates input and output. If a company generates a large volume of sale, it may be effective in using its capital investment - that gives an indication of efficency. It is important, however, for new ventures to generate sales first, for without sales there is no chance of earning any profit. Without effective operation to keep the venture alive, it will die before it can reach the promised land of profit.

For the reason, the focal point of an entrepreneurial strategy for a new venture often favours effectiveness rather than efficency. To turn out the first product and to land the first sale are far more important to new venture fiunders than worrying about efficie- ncy or profit.

For this reason, too, it is important for owner/managers not to get hung up on org- anization and structure. Too many corporate-style thinkers try to learn on organization for the firm's survival; their strategy then becomes survival, not innovation. Entrepreneuri- al thinkers concentrate on getting things done.

\section{Entrepreneurs and Entrepreneurial Capabilities}

Entrepreneurs are individuals, acting independently or as part of an organizati- on, who create a new venture or develop an innovation and take risks entering them into the marketplace. Entrepreneurs can be independent individuals or surface in an organizat- ion at any level. Thus, top-level managers, middle and first-level managers, staff personn- el, and those producing the company's good or service can all be entrepreneurs.

Firms need employees who think entrepreneurially. Top-level managers should try to establish an entrepreneurial culture that inspires individuals and groups to engage in corporate entrepreneurship. Apple Computer's Steve Jobs is committed to this effort, beleiving one of his key responsibilities is to help Apple become more entrepreneurial. And, Apple has introduced some innovately designed products., such as its recent iMac with its 15 -inch liquid crystal display attached to the base computer with a chrome swiv- el bar. Some believe that it looks more like a desk lamp. Apple is using the new design to capture a larger share of the PC market.

Of course, to create and commercialize products such as the iMac requires not on- ly intellectual capital, but an entrepreneurial mind-set as wll. It also requires entrepre- neurial competence. Returning to the Opening Case, entrepreneurial competence involv- es effective knowledge of the business and technology, a passion for the business, and a risk orientation. In most cases, knowledge must be trenasferred to other in the organizat- ion, even in smaller ventures, to enhance the entrepreneurial competence of the firm. The transfer is likely to be more difficult in large firms. Research has shown, however, that units within firms are more innovative if they have access to new knowledge.

Transfering knowledge can be difficult, because the receiving party must have ad- equate absorptive capacity to learn the knowledge. This requires that the new knowled- ge be linked to the existing knowledge. Thus, managers will need to develop the capabili- ties of their human capital to build on their current knowledge base while incrementally expanding that knowledge.

Developing innovations and achieving success in the marketplace requires effecti- ve human capital. In 
particular, firms must have strong human capital in their R\&D organization. However, a firm must have strong human capital throughout its workforce if employees are to be innovative. For example, Winspec West Manufacturing Inc. credits its positive market position to innovation produced by its strong employee base. In fact, the managers are very careful in hiring. Even in jobs with seemingly low challenges, they try to hire high potential employees. For one sekretarial position, the managers hired a person with an MBA in finance, that person went on to serve as the acting chief finacial officer.

Having the intellectual talent is only part of the challenge. The management of the talent to realize its potential is critical for a firm to be entrepreneurial. Managers must develop the culture and infuse it with the values espoused by successful entrepreneurs. Additionaly, managers should empower employees at all levels to act independetly.

People tend to perceive professionals as problem-solvers. If there is no problem, there is little need for professionals. For example, a happily married couple has not need to see a marriage consellor, a healthy person does not consult a psychiatrist. A bussiness running well and making a profit will not seek an outside consultant. If the foregoing sounds like an attack on professionals or professionalism, it isn't meant to be. Without a historical drive to develop professional standards, the world would still be relying on barbers to perform surgery and fortune tellers to predict the world economy. Proffesiona- lism - which means knowledge of and adherence to be abolished standards of performa- nce in a given field - is necessary for anyone who wonts to do more than middle throu- gh. This harmful only when it is allowed to stille initiative.

\section{International Entrepreneurship}

Entrepreneurship is a global phenomenon. It is the top of public policy agendas in many of the world's countries, including Finland, Germany, Israel, Ireland and France, among others. In Nortrhernd Irelamd, for example, the ministar for enterpri- se trade, and investment told business people that their current and future commercial success would be affected by the degree to which they decided to emphasize R\&D and innovation (critical components of entrepreneurship.

According to some researches who are studying economies throughout the world, virtually all industrial nations "are experiencing some form of tranasformation in their economies, from the dramatic move from centrally planned to market economies in East - central Europe to the efforts by Asian countries to return to their recent high growth levels.

While entrepreneurship is a global phenomenon, there are differences in the rate of entrepreneurship across countries. A recent study of 29 countries found that the perce- ntage of adults involved in entrepreneurial activity ranged from a high of more than 20 percent in Mexico to a low of approximately 5 percent in Belgium. The United States had a rate of about 13 percent. Importantly, this study also found a strong positive relations- hip between the rate of entrepreneurial activity and economic development in the count- ry.

Culture is one of the reasons for the differences in rates of entrepreneurship amo-ng different countries. For example, the tension between individualism and colectivism is important for entrepreneurship; research shows that entrepreneurship declines as colle- tivism is emphasized. Simultaneously, however, research results suggest that exceptiona- Ily high levels of individaul might be dysfuncional for entrepreneurship. Viewed collecti- vely, these results appear to call for a balance between individual initiative and a spirit of cooperation and group ownership of innovation. For firms to be entrepreneurial, they mu- st provide appropriate autonomy and incentives for individual initiative to surfice, but al- so promote cooperation and group ownership of an innovation if it is to be implement- ed successfully. Thus, entreprenurship often requires teams of people with unique skills and resources, expecially in cultures where collectivism is a valued historical norm.

Another important dimension of international entrepreneurship is the level of inv- estment outside of the home country made by young ventures. In fact, with increasing globalization, a greater number of new 
ventures have been born global." Research has sh- own that new ventures that enter international markets increase their learning of new tec- hnological and thereby enhance their performance. Because of these outcomes, the amou- unt of international entrepreneurship has been increasing in recent years.

The probability of entering international markets increases when the firm has top executives with international experience. Furthemore, the firm has a higher likelihood of successfully competing in international markets when its executives have international experience. Because of the learning and economics of scale and scope afforded by operating in international markets, both young and established internationally diversified firms often are stronger competitors in the domestic market as well. Additionaly, intern- ationally diversified forms are generally more innovative as research has shown.

International entrepreneurship have been an important factor in the economic dev- elopment of Asia. In fact, private companies owned by Chinese families outside of China compose the fourth largest economic power in the world. Significant learning from their international ventures occurs in these busuness, and this learning enhances their success with future ventures. The learning that occurs contributes to a firm's knowledge of opera- ting in international markets. It also contributes knowledge that can enhance a firm's new product develeopment, on which we focus in the next section.

\section{Creating Value from Innovation}

The model in Figure 1.1. shows how the firm can create value the internal proces- ses it uses to develop and commercialize new goods and services. An entrepreneurial mind-set is necessray so that managers and employees will consistently try to identify entrepreneurial opportunities that the firm can pursue by developing new goods and services and new markets. Cross-functional teams are important to promote integrated new product design ideas and commitment to their implmentation thereafter. Effective leadership and shared values promote integration and vision for innovation and commit- ment to it. The end result for the firm in the creation of value for the customers and share- holders through development and commercialization of new products.

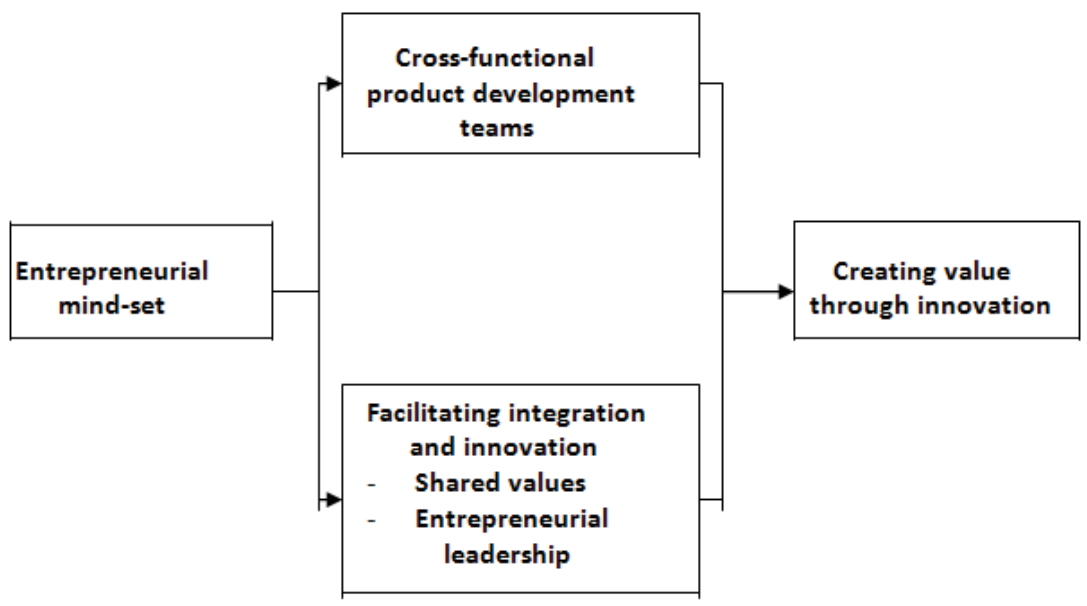

Figure 1.1. Creating Value through International Innovation Processes

\section{Creating Value through Strategic Entreprenurship}

Newer entrepreneurial firms often are more effective than larger firms in identify- ing opportunities. Some believe that these firms tend to be more innovative as well bec- ause of their flexibility and willingness to take 
risks. Alternatively, larger and well-established firms often have more resources and capabilities to exploit opportunities that are identified. So, younger, entrepreneurial firms are generally opportunity seeking and more established firms are advantage seeking. However, to compete effectively in the landscape of the $21^{\text {st }}$ century, firms must identify and exploit opportunities but do so while achieving and sustaining a competitive advantage. Thus, never experimental fi- rms must learn how to going a competitive advantage, and older more established firms must relain how to identify entrepreneurial opportunities. The concept of strategic entre- preneurship suggests that firms can be simultaneously entrepreneurial and strategy regar- dless of their size and age.

To be entreprenurial, firms must develop an entrepreneurial mind-set among their managers and employees. Managers must emphasize the development of their resources particularly human capital and social capital. The importnace of knowledge to identify and exploit opportunities as well as to gain and sustain a competitive advantage sugges- ts that firms must have strong human capital. Social capital is critical for access to complementary resources from partners in order to compete effectively in domestic and international markets.

There remain many entrepreneurial opportunities in international markets. Thus, firms should seek to enter compete in international markets. Firms can learn new techno- logies and management practices from internatioanl markets and diffuse this knowledge throughtout the firm. Furthermore, the knowledge firms gain can contribute to their inn- ovations. Research has shown that firms operating in international markets tend to be mo- re innovative. Small and large firms are now regularly moving into internatinal markets. Both types of firms must also be innovative to compete effectively. Thus, developing resources (human and social capital), taking advantage of opportunities in domestic and international markets, and using the resources and knowledge gained in these markets to be innovative, firms achieve competitive advantages. In so doing, they create value for their customers and shareholders.

Firms that practice strategic entrepreneurship contribute to a country 's econom- ic development. In fact, some countries such as Ireland have made dramatic economic progress by changing the institutional rules for business operating in the country. This could be construed as a form of institutional entrepreneurship. Likewise, firms that seek to establish their technology as a standard, also representing institutional entrepreneurs- hip, are engaging in strategic entrepreneurship because creating a standard produces a sustanable competitive advantage for the firm.

Research shows that because of its economic importance and individual motiv-es, enterpreneurial activity is increasing across the globe. Furhermore, more woman are becoming entrepreneurs because of the economic opportunity entrepreneurship provides and the individual independence it affords. In future years, entreprenurial activity may increase the wealth of less affluent countries. Regardless, the companies that practice strategic entrepreneurship are likely to be the winners in the $21^{\text {st }}$ century.

\section{Busines and Industry Profile}

To acquaint lenders and investors with the nature of the business, the owner sho- uld describe it in the buseness plan. This section should begin with a statesmen of the company's general business goals and a narrower definition of its immediate objectives. Together they should spell out what the business plans to accomplish, how, when, and who will do it. Goals are broad, long-range statesments of what a company plans to do in the distant future that guide its overall direction and express its raison d'etre. In order words, they answer the question."Why am I in busieness?" Answering such a basic quest- ion appears to be obvious, but, in fact, many entrepreneurs cannot define the basic of th- eir businesses. 


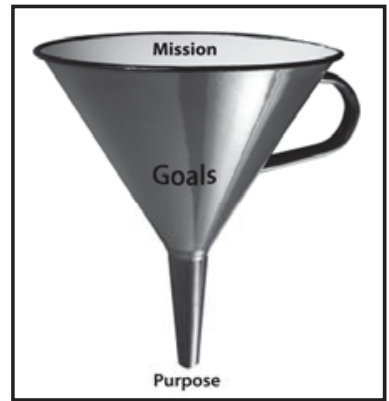

Figure 1.2. The Relationship Between Mission, Goals, and Objectives

Objectives, on the other hand, are short-term, specific performance targets thaat are attainable, measurable, and controllable. Every objective should reflect some gene- ral buseness goal and include a technique for measuring progress toward its accomplish- ment. To be meaningful, an objective must have a time frame for achievement. Both goa- Is and objectives should relate to the company's basic mission (see Figure 1.2.).

When summarizing the small company's background, an owner should describe the present state of the art in industry and what she will need to succeed in the market segment in which her business will compete. The owner should then identify the current applications of the product or service in the market and include projections for future applications.

This section should provide the reader with an overview of the industry or market segment in which the new venture will operate. Industry data such as market size, growth trends, and relative economic and competitive strenghts of the major firms in the servi- industry all set the stage for a better understanding of the viability of the new product or service. Strategic issues such as ease of market entry and exit, the ability to achieve eco- nomies of scale or scope, and the existence of cyclical or seasonal economic trends furth- er help the reader evaluate the new venture. This part of the plan also should describe significant and industry trends and an overall outlook for its future. The U.S. Industrial Outlook Handbook is an excellent reference that profiles a variety of industries and offers projections for future trends in them. Information about the evolution of the industry hel- $p s$ the reader comprehend its competitive dynamics.

The industry analysis should also focus on the existing an anticipated profitability of the firms in the targeted market segment. Any significant entry or exit of firms or con- solidations and merger should be disussed in terms of their impact on the competitive be- haviour of the market. The entrepreneur also should mention any events that have signifi- cantly altered the industry in the past years.

\section{Comparing Actual Rasults with Standards}

In the stage of the feedback loop, the idea is to look for deviation in either directi- on from the performance standards the company has set for itself. In other words, oppor- tunities to improve performance arise when there is a gap between "what should be" and "what is".(see Figure 1.3)

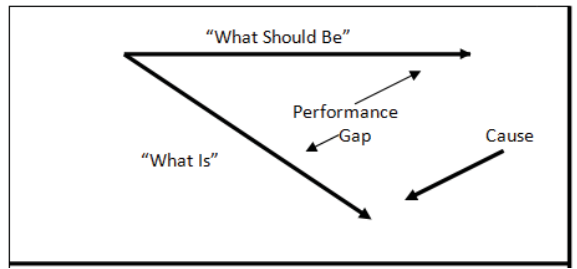

Figure 1.3. Comparing Actual Results with Performance Standards 
The most serious deviations usually are those where actual performance falls far below the standard. Managers and employees must focus their efforts on figuring out why actual performance is substandard. The goal is not to hunt down the guilty part (or parti- es) for punishment, but to discover the cause of the subpar performance and fix it! Mana- gers should not ignore deviations in the other direction, however. When actual performa- nce consistently exceeds the compay's standards, it is an indication that the standards are set too low. The company should look closely at "raising the bar another notch) to spur motivation.

\section{Summary}

Strategic entrepreneurship is taking entrepreneurial actions using a strategic perspective. More specifically, it involves engaging in simultaneous opportunity seeking and competitive advantage behaviors to design implement entreprenurial strateg- gies to create walth.

The concept of entreprenurial opportunity, innovation, and capabilities are impo- rtant to firms. Entrepreneurial opportunities represent conditions in which new produc- ts of services can satisfy a need in the market. The essence of entreprenurship to identify and exploit these opportunities. Innovation is the process of commercializing the produ- cts or processes that surfaced trough invention. Entrepreneurial capabilities include buil- ding an entrepreneurial culture, having a passion for the business and having a desire for measured risk.

Increasingly, entrepreneurship is being practiced in many countries. As used by entreprenurs, entrepreneurship and corporate entrepreneurship are strongly related to nation's economic growth. This relationship as a primary reason for the increasing use of entrepreneurship and corporate entreprenurship in countries throughout the global economy.

To create incremental and radical innovation requires effective processes. Increasingly, crossfunctional integration is vital to a firm's efforts to develop and implement internal corporate venturing activities and to comercialize the resulting innovation. Addi- tionaly, integration and innovation can be facilitated by the development of shared valu- es and the practice of entrepreneurial leadership.

The practice of strategic entreprenurship by all types of firms, large and small, new and more established, creates value for all stakeholders, especially for shareholde- rs and customers. Strategic entrepreneurship also contributes to the economic developm- ent of entire nations. Thus, entrepreneurial activity is increasing throughout the world.

\section{References}

S.M. Camp, L.W. Cox kotalik, 2001. The Hallmarks of Entrepreneurial Excellence: 2001 Survey of innovative Practices, Kaufman Center for Entreprenurial Leadreship, Ewing marion Kauftman Foundati on.

M.A. Hitt, R.D.Ireland, S.M. Camp\&D.L. Sextron, 2002. Strategic entrepreneurship integrating entreprenurial and strategic management perspectives, In M.A. Hitt, R.D. Ireland, S.M. Camp.7 D.L. Sexton (eds). Strategic Entrepreneurship Creating a New Minset. Pcford, U.K. Blacwell Publ,ishers, 1-Hitt, R.D.Ireland, S.M. Camp. \& D.L. Sexton, 2001. Strategic entrepreneurship. Entrepreneurial - strategies for weealth creating. Strategic management Journal, 22 Spewcial Issues 479-491., R.D. Irel and M.A Hitt, S.M. Camp\&D.L. Sexton, 2001. Integrating entrepreneurship and strategic managem ent action to create firm wealth, Academy of Management Executive 15(1): 49-63.

R.D. Ireland\&M.A.Hitt, 1999, Achieving and maintaining strategic cometitiveness in the 21 st century. The role of strategic leadership., Academy of Management Execurive, 13(1)43-57.

G. Hamel 2000. Leading The Revolution, Boston, mA Harvard Business School Press.

T.W. Man, T.Lau\&K.F. Chan, 2002. The competitiveness of small and medium enterprises: A conteptu alization with focus on entrepreneurial competences, Journal of Business Venturing, 17: 23-142.

S, Shane\& Veenkataraman, 2000. The promise of entrepreneurship as a field of research, Academy of Management Review, 25. 217-226.

R.G. McGrath \& I.MacMillan, 2000, The Entrepreneurial Minset, Boston, MA: Harvard Business School Press.

G.Gori, 2001. An American directs Mexico City's cinema revival, The New York Times, http//www. nytimes.com, July 15. 
P.F. Drucker, 1998. The discipline of innovation, Harvard Business Reviw 76(6);149-157. Schumpeter, The Theory of Economic Development.

S.D. Sarasvatty, 2000. Seminar on research perspectives in entrepreneurship (1997), Journal of Busi ness Venturing 15. 253-273.

Branislav Djordjevic, Entrepreneurship, Nis, 2011, 64 p.2001. Some like it hot. Entrepreneur com. October 30.

Branislav Djordjevic, Entrepreneurship, Nis, 2011, 239 p.R.G.McGrath, 200l. Expioratory learning, innovative capacity and managerial oversight, Acade-my of Management Journal, 44. 118-131.

M. Kvak, 2002. What's the best commercialization strategy for startups? MIT Sloan Manageme-ent Re view, 43(3); 10.

Hitt, Ireland. Camp.\&Sexton, Strategic entrepreneurship, S.W. Fowler, A.W.King, S.J. March \& Victor, 2000.. Beyond products: New strategic imperatives for developing competence in dynamic environments, Journal of Engineering and Rewchnology Management, 17, 357-377.

Amit, Lucier.Hitt\&Nixon, Strategies for the entreprenurial millenium.

Hitt, Ireland, Camp.\& Sexton, Strategies entreprenurship.

Hitt, Bierman, Shimizu\&Kochhar, Direct and moderating effects of human capital.

Reynolds, Camp. Bygrave, Autio \& Hay, Global Entrepreneurship Monitor.

Hitt, Ireland, Camp.\& Sexton, Strategies entrepreneurship, Amit, Lucier, Hitt\&Nixon, Strategies fo the entrepreneurial millenium.

Prof. dr B. Djordjevic, Psihologija menadzmenta, FIM-Krusevac, 2008. godina.

Thomas W. Zimmerer and Norman M. Scarborough, Essentials of Entrepreneurship and Small Bus iness Management", Sec. ed., 1998, pp. 284-285. 
